\title{
EFFECT OF THERMAL-VACUUM DISPERTION OF GRAPHITE
}

\author{
Volodymyr O. Kutovyi*, Dmitry G. Malykhin, Olexandr S. Kalchenko \\ Ruslan L. Vasilenko, Volodymyr D. Virych, Olexandr O. Germanov \\ National Scientific Center "Kharkov Institute of Physics \& Technology" NASU, \\ Kharkiv, 61108, Akademicheskaya st. 1, Ukraine \\ *Corresponding Author: kutovoy@kipt.kharkov.ua, Tel.: +38-057-349-10-82 \\ Received February 24, 2020; revised March 27, 2020; accepted March 29, 2020
}

\begin{abstract}
A scientific and technical development of a high-performance thermal-vacuum method, which is an environmentally friendly process based on combination of vacuuming and high-speed thermal heating, was carried out with non-stop production of nanodispersed carbon. A review of physical processes that affect a powder material has been carried out. Thermal-vacuum treatment of $\mathrm{C} 1$ grade graphite $1 \ldots 2 \mathrm{~mm}$ of size was carried out. To study the structural composition of the material in initial state and processed in a thermal-vacuum installation, X-ray diffraction analysis and electron microscopy were used. According to results of X-ray analysis, the original $\mathrm{C} 1$ grade graphite has two known structural modifications: hexagonal one with lattice periods $a_{\mathrm{o}}=0.2461 \mathrm{~nm}$, $c_{\mathrm{o}}=0.6705 \mathrm{~nm}$, and rhombohedral structure about $30 \%$ - with $a=0.2461 \mathrm{~nm}$ and $c=(3 / 2) c_{\mathrm{o}}=1.003 \mathrm{~nm}$. In graphite treated in a thermal-vacuum installation, these components have been detected as the main composition. Additionally, a super-structural rhombohedral phase with periods $a=2 a_{0}=0.492 \mathrm{~nm}$ and $c=(3 / 2) c_{0}=1.003 \mathrm{~nm}$ has been detected. A monoclinic phase with parameters $a_{1}=0.6075 \mathrm{~nm}, b_{1}=0.4477 \mathrm{~nm}, c_{1}=0.4913 \mathrm{~nm}$, and $\beta=99.6^{\circ}$ has also been detected, probably with the presence of iron atoms in structure. The results of analysis and calculations are generally consistent with TEM images of the reciprocal lattice of processed graphite. As a result, it was noted that the initial graphite powder was crushed to $2 \ldots 40 \mathrm{~nm}$ with a partial change in the structure, formation of objects like multilayer nanotubes and fullerenes. It was noted that thermal deformations are involved in this effect, what can significantly accelerate the process of obtaining nanodispersed carbon material with new physicochemical and mechanical properties. The results could be widely used for industrial production of nanosized materials.
\end{abstract}

KEY WORDS: carbon, thermal-vacuum dispersion, nanotubes, fullerenes.

Recently, it has become increasingly important to solve the problems of energy and resource conservation and intensification in production processes of nanodispersed materials. When dispersing materials in order to improve production cycle, in particular, several technological processes are combined in one installation. This leads to intensification of the production process and to lower capital costs. So, in some installations, the mechanical process of grinding and drying is used simultaneously [1]. In this case, preheated air is used for drying, what leads to essential energy demands. As a result of an analysis of the methods of fine grinding of materials, it was found that the most rational way is a combination of shock loads and erasure [2, 3]. Shock and erasure loads, which act in the field of intense turbulent flows, lead to destruction of the material with manifestation of new properties [4-7].

Due to the fact that among the tasks noted, much attention of the world community is paid to the use of carbon nanostructures in the industrial production, it would be advisable to test here similar dispersion methods with studying the properties of the obtained materials.

In this regard, the aim of this work is to investigate an effect of a thermal-vacuum dispersion process on state of C1 grade graphite.

\section{SCHEME OF THERMAL-VACUUM INSTALLATION FOR DISPERSION}

Used in this work, the thermovacuum method of non-stop dispersion of the material was developed on the basis of theoretical and experimental studies [8,9]. Its principle is based on the combination of fast vacuuming processes and contact heating of the surface of the particles of material inside a spiral heater, what provides instant heating of the surface layer of particles in vacuum to a predetermined temperature. Contact of the particles with the wall of the heater causes heat transfer to their surface layer, and the reduced pressure inside the heating element ultimately allows grinding the material layer by layer.

Figure 1 shows the thermal-vacuum installation designed for non-stop dispersing of powder materials [8].

The installation consists of a feed hopper (1), a hollow heater, (2), a vacuum pump (3), pipelines (4, 11), a cyclone (5), a dried raw material receiver (6), and a lock-gate (7). It has thermocouples $(8,13)$, a control panel (9), a conveyor (10), a filter (12), a level sensor for dried raw materials (14), and a vacuum gauge (15).

This design of the installation is able to provide non-stop dispersing of powder material in a space thermally insulated from the external environment.

\section{REGULARITIES OF HEAT-MASS-EXCHANGE PROCESSES IN THERMAL-VACUUM INSTALLATION}

An original coarse-grained material with ordinary humidity enters with the air inside the hollow spiral heater (2) (Fig. 1), and passes it for $15 \mathrm{~s}$ at a speed of $\sim 10 \mathrm{~m} / \mathrm{s}$. This is provided by creating a pressure gradient in the hollow heating element using a vacuum pump. Due to this, centrifugal force acts on the particles in the spiral hollow of the 
heater, and between the surface of particles and the wall of the heater at shortest times a dense shock contact is formed with an effective heat transfer. Instantaneous transfer of thermal energy from the heater wall to the surface layer of particles occurs $[9,10]$. The temperature change $(d T / d t)$ on the particle surface is determined by the temperature gradient $d T / d x$ at the moment of heat transfer from the heater in close contact with it:

$$
\frac{\partial T}{\partial t}=-\kappa \frac{d T}{d x}
$$

where $\kappa$ is a coefficient of thermal conductivity in the surface layer of the particle.

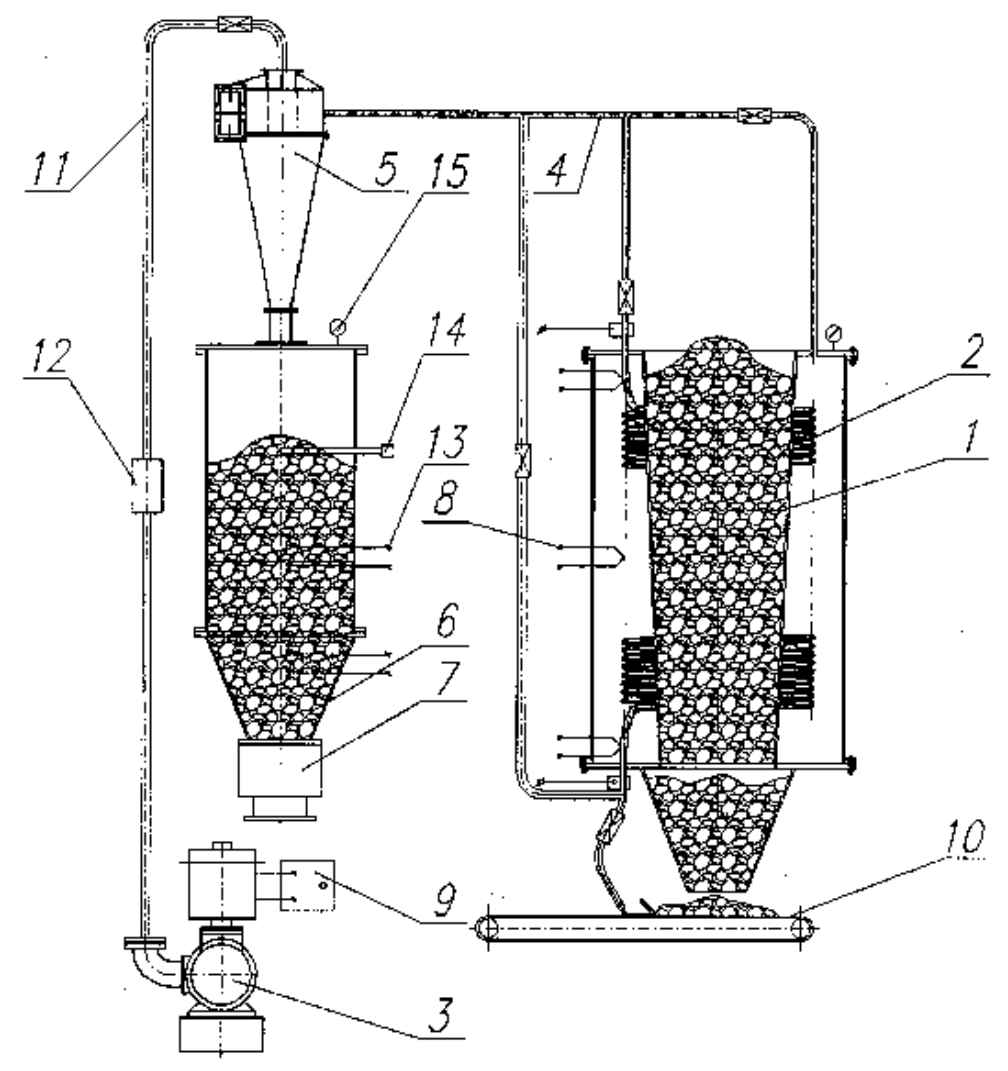

Fig.1. Scheme of thermal-vacuum installation.

A change in temperature leads to a change in the size of the heated section along the temperature front, i.e. along the contact surface: $\Delta l / l_{0}=\alpha \Delta T / T$, where $\alpha$ is the thermal coefficient of linear expansion of the material. The velocity of the medium at the conditional boundary of the heated section of radius $l_{0} / 2$ will eventually have the following expression:

$$
v_{l}=\frac{1}{2} \frac{d l}{d t}=\alpha \frac{l_{0}}{2} \frac{\partial T}{\partial t}=-\alpha \kappa \frac{l_{0}}{2} \frac{d T}{d x} .
$$

As is known from field theory and continuum mechanics, all field perturbations are described by functions of a type $f(x, t)=f\left(x-v_{s} \cdot t\right)$ and propagate with speed $v_{s}$. The time derivative of the argument $v_{s} \cdot t-x$ is here the "Doppler" sound speed in the coordinates of the boundary of that section: $v_{s}-v_{l}$. Its relationship with the sound speed $v_{s}-v_{l} \leftrightarrow v_{s}$ indicates the compression degree of that boundary medium, and a rough estimate of the stress in this section can be represented by the following formula:

$$
\sigma \sim C_{11} \frac{v_{l}}{v_{s}-v_{l}}
$$

where $C_{11}$ is an uniaxial compression module of the medium.

Thus, the effect of particle crushing, similar to the action of a shock wave, manifests itself at $v_{l} \sim v_{s}$ and even at lower $v_{l}$ speeds. In addition, since the temperature gradient $d T / d x(1-2)$ depends on the initial moment of contact inversely with $t^{n}$, where $n \sim 1$, this effect can occur in the shortest initial time intervals and with sufficiently small fragments of particles [11]. Such effects are known to be accompanied by audible characteristic crackles. At the same time, high stresses arising in such a process can significantly affect the crystalline structure of materials, like martensitic transformations. 
It is known that the powders of many materials are hygroscopic and can contain from percent to tens of percent humidity. Then, since with sharp contact heating, the dispersion effect comprises microscopic sections of the material, the residual humidity in such cases can significantly affect the process. The essence of this is a sharp thermal expansion of water particles during the formation of water vapor - in a vapor explosion, which can significantly intensify the dispersion effect [11].

In general, the effectiveness of dispersion in a thermal-vacuum installation depends on the thermophysical properties of material and its state: on the relationships between thermal conductivity, heat capacity and thermal expansion, on dispersion and humidity of original material, on temperature of heater and pressure inside the channel.

\section{MATERIAL AND METHODS}

For processing in the thermal-vacuum installation, we chose the $\mathrm{C} 1$ grade graphite with $1 \ldots 2 \mathrm{~mm}$ size of particles (Fig. 2a) and 1.0...1.5\% total impurity according mass spectrometry.

$\mathrm{X}$-ray diffraction analysis was used to investigate the structural composition of the graphite material in the original and processed state. The samples were made in the form of briquettes $\varnothing 25.0 \times 5 \ldots 10 \mathrm{~mm}^{2}$ by pressing with $250 \mathrm{MPa}$ pressure. The measurements were carried out by the DRON4-07 diffractometer according to the Bragg-Brentano X-ray optical scheme with a proportional counter. To eliminate the vertical divergence of the X-ray beam, a pair of Soller slits was used in the measurement scheme. In the initial processing of the obtained data, the reflection angles were corrected by eliminating the effect of the depth of reflection of radiation, which for dense graphite gives an X-ray line shift in order of part of degree, and this effect is enhanced when measuring the powder with a lower density.

For electron-optical studies of structure of the material, the JEM-100CX transmission microscope was used. For this, a light fraction of the material was released by aquatic flotation.

The chemical composition was determined using the EMAL-2 laser mass spectrometer.

\section{RESULTS AND DISCUSSION}

Table 1 shows the mass-spectrometric data on the chemical composition of the treated graphite.

Table 1.

Chemical composition of treated the $\mathrm{C} 1$ grade graphite.

\begin{tabular}{|c|ccccccccccc|}
\hline element & $\mathrm{Fe}$ & $\mathrm{Ca}$ & $\mathrm{Si}$ & $\mathrm{Al}$ & $\mathrm{K}$ & $\mathrm{Na}$ & $\mathrm{Mg}$ & $\mathrm{Ti}$ & $\mathrm{S}$ & $\mathrm{Mn}$ & rest \\
\hline$\% \mathrm{wt}$ & 3,1 & 2,9 & 0,94 & 0,7 & 0,68 & 0,5 & 0,47 & 0,3 & 0,24 & 0,1 & $<0.2$ \\
\hline
\end{tabular}

The bulk density of the material is $0.316 \mathrm{~g} / \mathrm{cm}^{3}$.

By thermal-vacuum treatment, a nanodispersed graphite powder was obtained with decreasing in particle size to nanometer. Aggregations of particles with $10 \ldots 40 \mathrm{~nm}$ size were also detected (Fig. 2b). It is considered that these are particles of an intermediate state that have been granulated during processing.
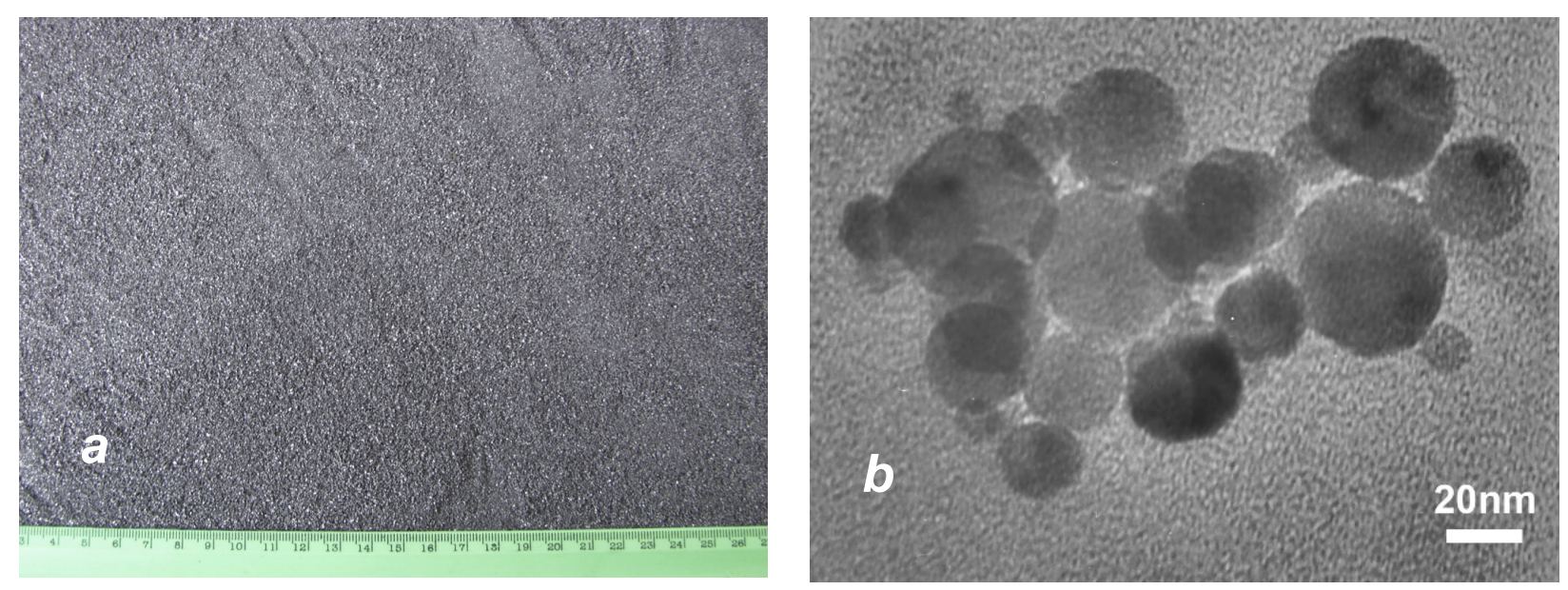

Figure 2. $\mathrm{C} 1$ graphite in the initial state (a) and after treatment (b; SEM image).

Figure 3 presents TEM images of the reciprocal lattice of the heat-treated graphite. Figure 3a shows it for a graphite particle having the ordinary hexagonal or rhombohedral lattice with its reflection here in the basal crystallographic plane (Fig. 3a). This particle also includes a coherent phase with a double period a, which follows from the hexagonal arrangement of small points in close proximity to the center of the electron-diffraction scan. The reciprocal lattice of the monoclinic modification with an angle $\beta=99.5^{\circ}$ was also recorded (Fig. 3b).

From these results it follows that, during processing, some of the graphite is transformed to a new modification.

According to Figure 4, in the heat-treated graphite $\mathrm{C}$, formations similar to multilayer nanotubes and fullerenes with sizes of $2 \ldots 5 \mathrm{~nm}$ and $2 \mathrm{~nm}$, respectively, are observed. 
Figure 5 presents fragments of $2 \theta$-angular $\mathrm{CuK}_{\alpha}$ diagrams of intensity of X-ray reflections of the $\mathrm{C} 1$ graphite in the initial and heat-treated state. According to the results of measurements and calculations, the original graphite consists of two known components: the hexagonal phase with periods $a_{\mathrm{o}}=0.2461 \pm 0.0002 \mathrm{~nm}, c_{\mathrm{o}}=0.6705 \pm 0.0007 \mathrm{~nm}$, the rhombohedral component with periods $a=a_{\mathrm{o}}=0.2461 \pm 0.0001 \mathrm{~nm}$ and $c=(3 / 2) c_{\mathrm{o}}=1.0030 \pm 0.0002 \mathrm{~nm}$ with a content of about $30 \%$ (Fig. $5 \mathrm{a}$ ).

As the main composition, these phases have also been detected with the same mutual proportion in the heat-treated graphite. Additionally, a modified (superstructural) rhombohedral phase was found in it with the double period $a$ : $a_{1}=2 a_{\mathrm{o}}=0.492 \pm 0.0001 \mathrm{~nm}$ and $c_{1}=c_{\mathrm{o}}=1.0030 \pm 0.0002 \mathrm{~nm}$. According to Figure $3 \mathrm{a}$, this phase is coherent with the main graphite modification. A monoclinic phase was also found with the following lattice periods: $a_{2}=0.6075 \pm 0.0001 \mathrm{~nm} ; b_{2}=0.4477 \pm 0.0002 \mathrm{~nm} ; c_{2}=0.4913 \pm 0.0003 \mathrm{~nm}$ and $\beta=99.6 \pm 0.1^{\circ}$. Probably, this structure was formed with the participation of iron atoms. The proportions and the angle value are consistent with the results of a TEM scan of the reciprocal lattice of the treated graphite (Fig. 3b).
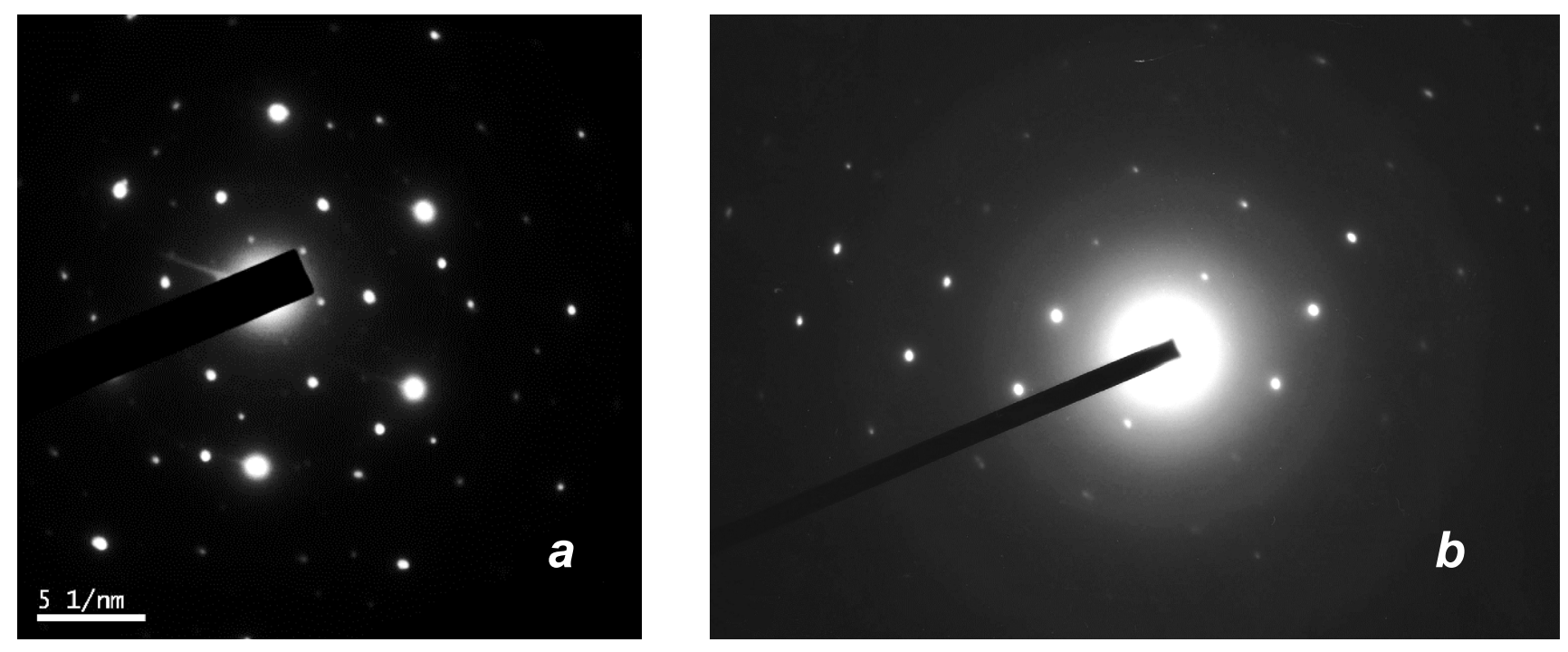

Figure 3. Electron-diffraction scans of hexagonal (a) and monoclinic (b) reciprocal lattices in the C1graphite after treatment.
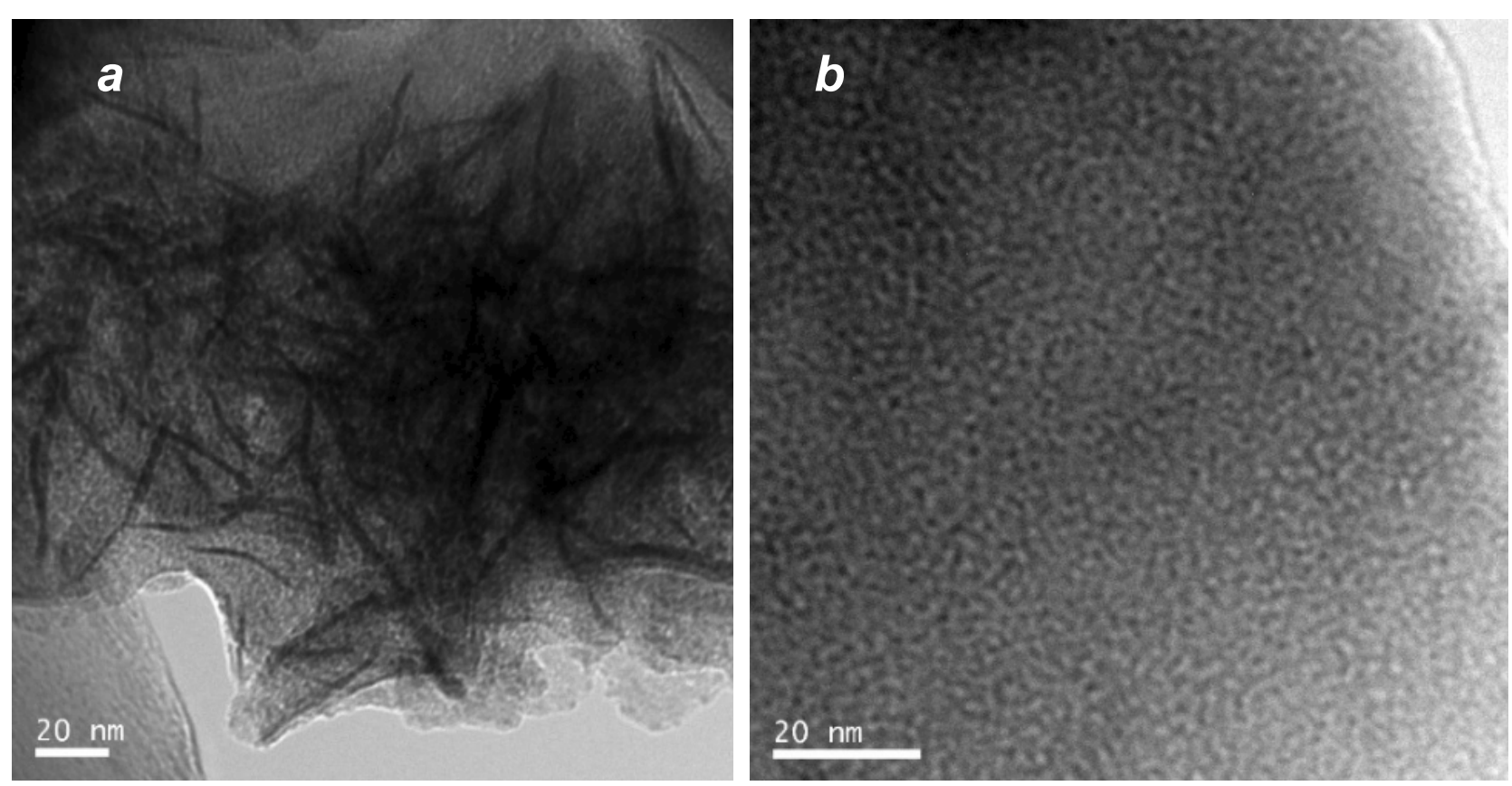

Figure 4. TEM illustrations of multilayer nanotubes (a) and fullerene-like formations (b) in the treated C1 graphite. 
Table 2 presents the results of calculations of structures, including interplanar distances and reflection indices (in increasing angle): initial graphite with hexagonal and rhombohedral structure, as well as phases formed with superstructural rhombohedral and monoclinic systems.

Table 2.

Interplanar spacing $(d)$ on the measurements of the treated graphite $\mathrm{C} 1$, and $(h k . l)$ indices of the found phases: hexagonal, rhombohedral (RE), modified (superstructural) rhombohedral (RE'), and monoclinic system.

\begin{tabular}{|c|c|c|c|c|c|c|c|c|c|c|c|c|c|c|}
\hline \multirow{2}{*}{$\begin{array}{c}d \\
(\mathrm{~nm})\end{array}$} & \multicolumn{4}{|c|}{ Structure; $(h k . l)$} & \multirow{2}{*}{$\begin{array}{c}d \\
(\mathrm{~nm})\end{array}$} & \multicolumn{4}{|c|}{ Structure; $(h k . l)$} & \multirow{2}{*}{$\begin{array}{c}d \\
(\mathrm{~nm})\end{array}$} & \multicolumn{4}{|c|}{ Structure; $(h k . l)$} \\
\hline & Hex. & RE & RE' & Mono. & & Hex. & RE & $\mathrm{RE}^{\prime}$ & Mono. & & Hex. & RE & RE' & Mono. \\
\hline 0,4265 & & & $(10.0)$ & & 0,2084 & & $(10.1)$ & $(20.1)$ & & 0,1816 & & & $(10.5)$ & \\
\hline 0,3932 & & & & $(1-10)$ & 0,2083 & & & & $(1-12)$ & 0,1800 & $(10.2)$ & & & \\
\hline 0,3925 & & & $(10.1)$ & & 0,2036 & & & & $(021)$ & 0,1739 & & & & $(310)$ \\
\hline 0,3355 & $(00.2)$ & & & & 0,2033 & $(10.1)$ & & & & 0,1693 & & & & $(212)$ \\
\hline 0,3345 & & $(00.3)$ & $(00.3)$ & $(110)$ & 0,2026 & & & & $(1-21)$ & 0,1678 & $(00.4)$ & & & \\
\hline 0,3249 & & & $(10.2)$ & & 0,2025 & & & & $(300)$ & 0,1672 & & $(00.6)$ & $(00.6)$ & $(220)$ \\
\hline 0,3069 & & & & $(1-11)$ & 0,1994 & & & & $(120)$ & 0,1645 & & & & $(3-20)$ \\
\hline 0,3037 & & & & $(200)$ & 0,1983 & & & (11.3) & & 0,1625 & & (10.4) & (20.4) & \\
\hline 0,2462 & & & $(11.0)$ & & 0,1973 & & & & $(3-10)$ & 0,1560 & & & & $(3-21)$ \\
\hline 0,2455 & & & & $(002)$ & 0,1979 & & & & $(112)$ & 0,1544 & $(10.3)$ & & & \\
\hline 0,2390 & & & & $(2-11)$ & 0,1966 & & & & $(2-20)$ & 0,1538 & & & & $(3-12)$ \\
\hline 0,2276 & & & & $(102)$ & 0,1963 & & $(10.2)$ & $(20.2)$ & & 0,1537 & & & & $(013)$ \\
\hline 0,2237 & & & & $(020)$ & 0,1909 & & & & $(202)$ & 0,1535 & & & $(21.2)$ & \\
\hline 0,2133 & $(10.0)$ & & & & 0,1872 & & & & (301) & 0,1535 & & & & $(2-22)$ \\
\hline
\end{tabular}
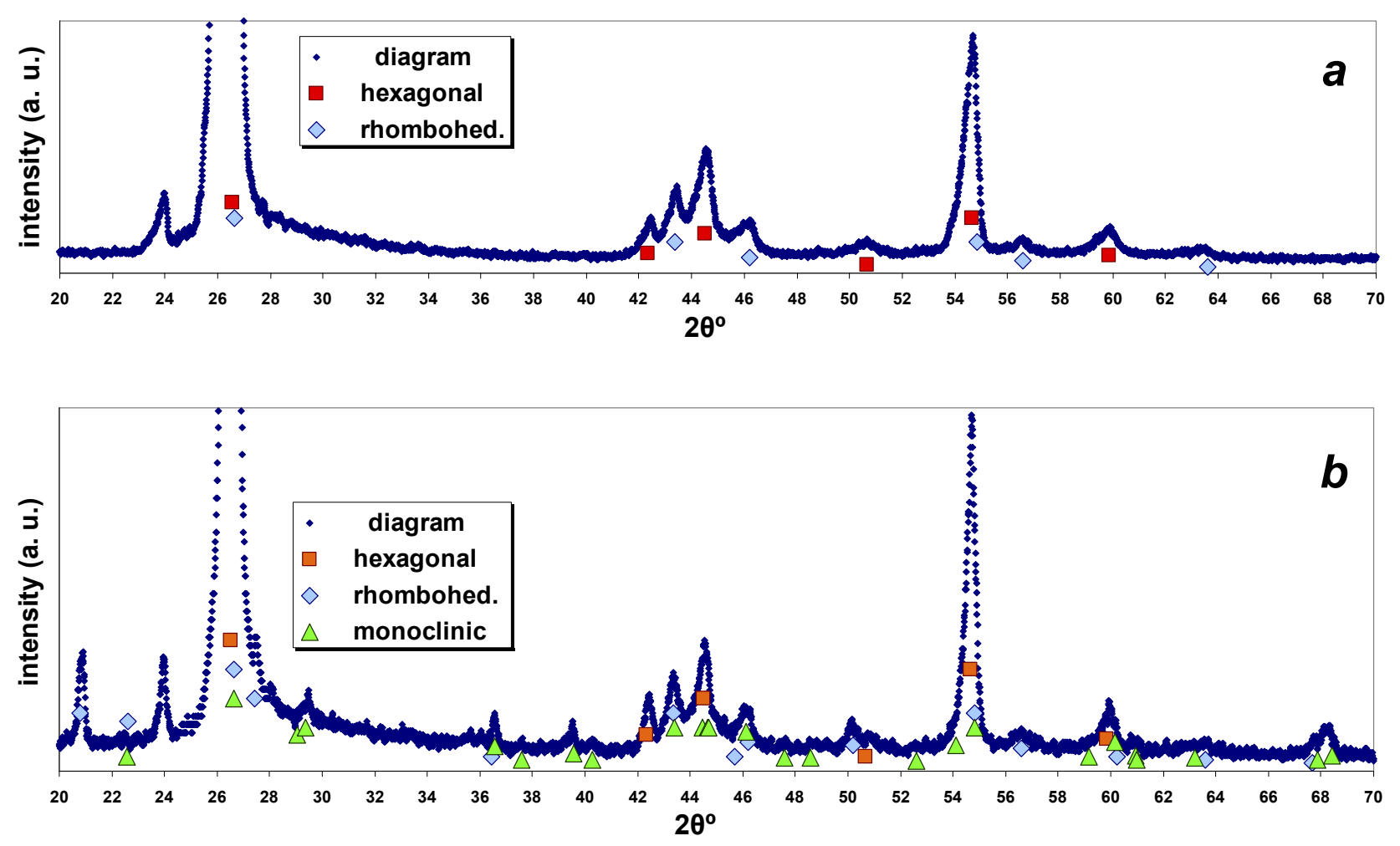

Figure 5. Fragments of X-ray scans with the designations of calculated reflection angles for the components of the $\mathrm{C} 1$ graphite in the original (a) and processed state (b).

Thus, movement of carbon powder in the hollow of the spiral heating element of the thermal-vacuum installation leads to its dispersion, converting the original material for $15 \mathrm{~s}$ (with a productivity of $8 \ldots 9 \mathrm{~g} / \mathrm{s}$ ) into nanodispersed state with order of $2 \ldots 40 \mathrm{~nm}$ particle sizes and with modification of structure of some part material.

It should be noted that the total continuance of the production of nanodispersed carbon in the thermal-vacuum installation counts some seconds, due to rapid heating and reduced ambient pressure. For the effective intake of carbon in the installation, a stream of air is necessary such that will ensure its continuous movement inside the spiral heating element. 


\section{CONCLUSION}

The process of high-speed dispersion of powders, based on the combination of mechanics of particle motion under conditions of rapid evacuation, and thermal effects on particles, has been described and analyzed. A thermal-vacuum installation in which these processes are combined has been described.

By combining these processes in the thermal-vacuum installation, the processing of $\mathrm{C} 1$ grade graphite powder with an initial particle size of $1 . .2 \mathrm{~mm}$ was carried out. The following results were obtained:

As a result of the dispersion process, a powder is formed with particle sizes of the order of a nanometer with $10 \ldots .40 \mathrm{~nm}$ residual granular particles. It has been established that the nanometer sizes are both nanotubes forming multilayer complexes and fullerene-like formations.

In addition to the ordinary phases of the original graphite, which have a hexagonal and a rhombohedral lattices, and are detected in the treated powder as the main composition, a superstructural-rhombohedral phase was also found in the treated powder, as well as a monoclinic phase was with the probable participation of iron atoms.

As a result, in the graphite's example, it was shown that the described thermal-vacuum treatment of coarse-grained materials is capable of dispersing them rapidly and energy-efficiently with a partial change in the crystalline structure and even in particle shape.

DDmitry Malykhin, https://orcid.org/0000-0003-0259-0211

\section{ORCID IDs}

\section{REFERENCES}

[1] N.I. Shishkov, S.A. Oparin, P.I. Soroka, and V.I. Zrajevsky, in: Proceedings of V International research-to-practice conference Science and Education, (Dnepropetrovsk - Donetsk, 2002). 19, pp. 49-50.

[2] S.A. Oparin, and P.I. Soroka, Наукові праці Одеської національної академії харчових технологій [Scientific works of Odessa National academy of food technology], 45(3), 4-9 (2014).

[3] S.A. Oparin, Ye.V. Leshchenko, and P.I. Soroka, Наукові праці Одеської національної академії харчових технологій [Scientific works of Odessa National academy of food technology], 37, 118-122 (2010).

[4] A.V. Mikhailenko, S.Yu. Smyk, and Yu.A. Kunitsky, Поверхность [Surface], 3(18), 50-102 (2011).

[5] Brychka S.Yа. Наноструктурное материаловедение [Nanostructured materials science], 2, 40-53 (2009).

[6] Q. Zhang, S.F. Yoon, J. Ahn et al. Journal of Physics and Chemistry of Solids, 61(7), 1179-1183 (2000), https://doi.org/10.1016/S0022-3697(99)00383-2.

[7] Y.S. Woo, N.S. Lee, D.Y. Han et al. Diamond and Related Materials, 11, 59-66 (2002). https://doi.org/10.1016/S09259635(01)00519-2.

[8] V.O. Kutovoy, Patent of Ukraine No 81138, (27 July 2005). Vacuum drying device, N a200507488; stated 27 July 2005 ; publ. 10 December 2007. Bull. N 20, pp. 5.

[9] V.O. Kutovoy, and I.S. Mysak, East-European Journal of Advanced Technology, 6/8(72), 35-40 (2014).

[10] V.I. Isachenko, V.A. Osipova, A.S. Sukomel, Tenлоnередача [Heat conductance]. (Energoizdat, Moscow, 1981$)$, pp. 417.

[11] V.O. Kutovoy, D.G. Malykhin, O.S. Kalchenko, and R.L. Vasilenco, Digest of scientific papers, Поверхность [Surface], 11(26), 508-520 (2019).

\section{ЕФЕКТ ТЕРМОВАКУУМНОГО ДИСПЕРГУВАННЯ ГРАФІТУ}

Кутовий В.О., Малихін Д.Г., Кальченко О.С., Василенко Р.Л., Вірич В.Д., Германов О.О.

Національний науковий центр «Харківський фізико-технічний інститут» НАНУ

Харків, 61108, вул. Академічна 1, Україна.

Здійснено науково-технічну розробку екологічно чистого, високопродуктивного термовакуумного методу безперервного виробництва нанодисперсних порошків, що виконано на підставі об'єднання процесу вакуумування i швидкісного термічного нагріву. Проведено аналіз фізичних процесів в термовакуумній установці, що впливають на частинки вихідного матеріалу. Проведено термовакуумну обробку графіту марки С1 з вихідним розміром частинок у $1 . . .2$ мм. Для дослідження структурного складу матеріалу в початковому стані і обробленого в термовакуумній установці застосовано рентгеноструктурний аналіз та електронну мікроскопію. Згідно з результатами рентгеноструктурних досліджень, вихідний графіт марки С1 має дві відомі структурні модифікації: гексагональну з періодами решітки $a_{\mathrm{o}}=0.2461 \mathrm{HM}, c_{\mathrm{o}}=0.6705 \mathrm{Hм} \mathrm{i}$ ромбоедричну з вмістом близько $30 \%$ та 3 періодами $a=0.2461$ нм и $c=1.003$ нм (полуторне значення періоду $c_{\text {о }}$ основної структури графіту). Поєднання цих фаз спостерігалося в основі складу графіту С1 після обробки в термовакуумній установці. Крім цього додатково виявлено надструктурну ромбоедричну фазу 3 періодами $a=2 a_{0}=0.492$ нм $\mathrm{i}$ $c=(3 / 2) c_{\mathrm{o}}=1.003$ нм. Виявлено також фазу 3 моноклінною структурою і з параметрами $a_{1}=0.6075 \mathrm{Hм} ; b_{1}=0.4477 \mathrm{Hм}$; $c_{1}=0.4913$ нм; $\beta=99.6^{\circ}$ - імовірно, з наявністю в структурі атомів заліза. Результати аналізу і розрахунків в цілому узгоджуються з ПЕМ-знімками зворотної кристалічної гратки обробленого графіту. В результаті відзначено, що вихідний порошок графіту піддався дробленню до розмірів $2 \ldots 40$ нм з частковою зміною структури та 3 проявом форм, подібних багатошаровим нанотрубкам і фулеренам. Також відзначається, що в цьому процесі беруть участь термодеформаційні ефекти, що дозволяе значно прискорити процес отримання нанодисперсного вуглецевого матеріалу 3 новими фізикохімічними і механічними властивостями. Отримані результати можуть знайти широке застосування для промислового виробництва нанодисперсних матеріалів.

КЛЮЧОВІ СЛОВА: вуглець, термовакуумне диспергування, нанотрубки, фулерени 


\section{ЭФФЕКТ ТЕРМОВАКУУМНОГО ДИСПЕРГИРОВАНИЯ ГРАФИТА}

Кутовой В.А., Малыхин Д.Г., Кальченко А.С., Василенко Р.Л., Вирич В.Д., Германов А.А.

Национальный научный центр «Харьковский физико-технический институт» НАНУ Харьков, 61108, ул. Академическая 1, Украина

Осуществлена научно-техническая разработка экологически чистого, высокопроизводительного термовакуумного метода непрерывного производства наноодисперсных порошков, выполненная на основании объединения процесса вакуумирования и скоростного термического нагрева. Проведен анализ физических процессов в термовакуумной установке, которые воздействуют на частицы исходного материала. Проведена термовакуумная обработка графита марки С1 c исходным размером частиц $1 \ldots 2$ мм. Для исследования структурного состава материала в исходном состоянии и обработанного в термовакуумной установке использован рентгеноструктурный анализ и электронная микроскопия. Согласно результатам рентгеноструктурных исследований, исходный графит марки С1 имеет две известные структурные модификации: гексагональную с периодами решётки $a_{\mathrm{o}}=0.2461 \pm 0.0002 \mathrm{Hм}, c_{\mathrm{o}}=0.6705 \pm 0.0007$ нм и ромбоэдрическую с содержанием порядка $30 \%$ - с периодами $a=0.2461 \pm 0.0001$ нм и $c=1.003 \pm 0.0002$ нм (полуторное значение периода $c_{\mathrm{o}}$ основной структуры графита). Сочетание этих фаз наблюдалось в основе состава графита С1 после обработки в термовакуумной установке. Помимо этого дополнительно обнаружена сверхструктурная ромбоэдрическая фаза с периодами $a=2 a_{\mathrm{o}}=0.492 \pm 0.0001 \mathrm{нм}$ и $c=(3 / 2) c_{\mathrm{o}}=1.003 \pm 0.0002$ нм. Обнаружена также фаза с моноклинной структурой и с параметрами $a_{1}=0.6075 \pm 0.0001 \mathrm{Hм;} b_{1}=0.4477 \pm 0.0002 \mathrm{Hм} ; c_{1}=0.4913 \pm 0.0003 \mathrm{Hм} ; \beta=99.6 \pm 0.1^{\circ}-$ предположительно, $\mathrm{c}$ наличием в структуре атомов железа. Результаты анализа и расчётов в целом согласуются с ПЭМ-снимками обратной решётки обработанного графита. В результате отмечено, что исходный порошок графита подвергся дроблению до размеров $2 \ldots 40$ нм с частичным изменением структуры и с проявлением форм, подобных многослойным нанотрубкам и фуллеренам. Отмечается также, что в этом процессе участвуют термодеформационные эффекты, что позволяет значительно ускорить процесс получения нанодисперсного углеродного материала с новыми физико-химическими и механическими свойствами. Полученные результаты могут найти широкое применение для промышленного производства нанодисперсных материалов. КЛЮЧЕВЫЕ СЛОВА: углерод, термовакуумное диспергирование, нанотрубки, фуллерены 